correct period. The skewness of the distribution suggests a bias towards slower rather than more rapid rates. Surprisingly perhaps this bias seems less evident when the solutions contained additives, though in this subgroup the proportion of correctly administered solutions was higher.

It seems likely that the methods used in our survey will underestimate the true extent and size of variations in rate. Because we measured only the mean infusion rate shortterm decreases or increases would be missed. Attempts to correct these variations are commonly encountered in the ward as efforts to "get the bottle through in time" or to "slow it down a bit until we have someone free to change it." We look forward to hearing about the servo-controlled regulating clamp mentioned by Drs. Flack and Whyte, which will take a little of the uncertainty out of intravenous infusion therapy.-We are, etc.,

D. M. Chaput de Saintonge Department of Pharmacology and Therapeutics,

JANE DIXON

Department of Nursing

MAYNARD S. NEWMAN

Department of Pharmacy,

Hospital (Whitechapel) London E.1

\section{Kidneys for Transplantation}

SIR,-I would certainly endorse Mrs. Elizabeth J. Ward's plea for doctors to help the supply of viable cadaver kidneys to transplant surgical teams. I cannot, however, agree that patients undergoing regular haemodialysis are relegated to "uselessness and wretchedness." Many patients are able to continue their work or continue to do normal household chores.-I am, etc.,

Department of Medicine

A. O. Frank

University Hospital

Kuala Lumpur
Malaysia

\section{Tapeworms and Isolation}

SIR,-I am pleased to see the warning by Dr. F. J .Wright (14 September, p. 685) on the danger presented by carriers of Taenia solium. The eggs passed by such patients are a danger not only to themselves but also to all around them. In many parts of the world cysticercosis is a common cause of adult-onset epilepsy ${ }^{12}$ and of other obscure nervous conditions, and if serology $y^{3}$ is any criterion is far more prevalent than presentation of the adult worm.

However, it would be manifestly impossible to isolate all cases of taeniasis and one would therefore make a plea for adequate species identification of tapeworms encountered. The number of branches to the gravid uterus is not a reliable criterion, the mature bisexual segments giving more information." These should be submitted to an adequately informed laboratory.-I am, etc.,

\section{R. ELSDON-DEW}

\section{Amoebiasis Research Unit,}

Durban, South Africa 1 Powell, S. J., et al., Annals of Tropical Medicine
2 Powell, S. J., et al., Annals of Tropical Medicine and Parasitology, 1966, 60, 159

R A tor, E. M., Powell, S. J., and Elsdon-Dew, ology, 1966, 60, 146. Proctor, E. M., South African Medical fournal,
1972, 46, 234.

\section{Variability in Response to Drugs}

SIR,-Professor M. D. Rawlins's survey, "Variability in Response to Drugs" (12 October, p. 91) contained much useful information. However, we wish to comment on the section on nortriptyline. This states that "the therapeutic effect of nortriptyline in the treatment of endogenous depression occurs only at plasma concentrations of 50 to 140 $\mathrm{ng} / \mathrm{ml}$." This conclusion is one reached by Âsberg et al.1 They studied the relation between plasma concentration of nortriptyline and therapeutic effect after two weeks' treatment in 29 depressed patients. A period of two weeks is not adequate to assess the therapeutic effects of tricyclic antidepressants: four weeks is a minimal period. In addition, the patients in their study received hypnotics including pentobarbitone. Barbiturates have been shown to lower plasma tricyclic levels significantly. ${ }^{2}$ Our contention is that the quoted study does not prove what Professor Rawlins states to be factual. Studies on the relation between clinical response and plasma tricyclic levels have produced conflicting results, ${ }^{45}$ so that dogmatic statements in this field are inappropriate.

Several years of study in this field have shown us that studies of groups of depressed patients using a fixed oral dosage of tricyclics show different results to studies of individual patients receiving changing amounts of daily oral medication. ${ }^{6}$ Studies of individual depressed patients have shown some patients who respond only to high oral dosage and high plasma levels (that is, 200-300 ng/ml) of nortriptyline. ${ }^{7}$ We recognize, as do most clinical psychiatrists, that some depressed patients do not respond to tricyclics whatever the oral dosage or plasma levels of the drug.-We are, etc.

Graham D. BuRRows BRIAN DAVIES

Department of Psychiatry,

Royal M

Victoria,

1 Åsberg, M., et al., British Medical fournal, 1971, Asberg,

Sjöqvist, et al., Proceedings of the European
Society for the Study of Drug Toxicity. Vol, 9, Society for the Study of Drug Toxicity. Vol, 9, Excerta Medica, Inter

No. 145, p. 246, 1967.
Burrows, G. D., and Davies, B., British Medical fournal, 1971, 4, 113 .

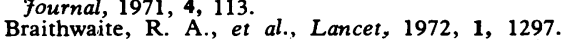
Burrows, G. D., Davies, B., and Scoggins, B. A., Lancet, 1972, 2, 619 .

Lancet, 1972, 2, 619.
Burrows, G. D., et al., Clinical Pharmacology and Therapeutics, $1974,16,639$.

Burrows, G. D., M.D. Thesis, 1972. University of Melbourne.

Comparison between Free Thyroxine Index and Effective Thyroxine Ratio

SIR,-In order to assess the value of a new in vitro thyroid function test, the effective thyroxine ratio (E.T.R.), Dr. E. G. M. D'Haene and others (21 September, p. 708) have compared this test with its present alternative, the free thyroxine index (F.T.I.). Comparisons were made with both Pearson's and Spearman's correlation analysis and the resulting coefficients were remarkably different (Pearson's $r_{p}=+0.84$ and Spearman's $\left.r_{s}=+0.68\right)$.

I agree with the authors when they criticize previous similar studies in which r $\mathbf{P}$ was reported on data from inhomogenepopulations comprising hypo-, eu-, and hyperthyroid subjects. Under these circumstances a Gaussian distribution is very unlikely and a distribution-free method should be used like the rank correlation devised by Spearman. However, when agreement to the kind of correlation analysis has been reached, there remains another item making comparisons between different studies difficultthat is, differences in relative sizes of the subpopulations.

In a similar study Wellby et al. ${ }^{1}$ found highly significant correlation coefficients in myxedematous $(\mathrm{r}=+0.71, \mathrm{n}=21)$ and thyrotoxic $(\mathrm{r}=+0.90, \mathrm{n}=27)$ patients, but a non-significant correlation in normals ( $\mathrm{r}=+0 \cdot 19, \mathrm{n}=28$ ) yielding a "pooled" coefficient of $+0.95(n=76)$. The kind of correlation analysis used is not presented in their paper, but is assumed to be that of Pearson.

We have measured the E.T.R. and calculated an F.T.I. (product of a noncommercial total thyroxine method and triodothyronine (T3) resin uptake by the Triosorb method) in consecutive, non-selected blood donors and non-treated thyroid inpatients. Correlation analysis with both methods mentioned gave the following results: 79 blood donors, $r_{p}=+0.16$ and $r_{\mathrm{S}}=+0.36 ; 43$ thyroid patients, $r_{P}=$ +0.92 and $r_{s}=+0.85$; and all samples pooled $r_{P}=+0.71$ and $r_{s}=+0.62$. These figures confirm the poor correlation between E.T.R. and F.T.I. in normal individuals reported by Wellby et al. Whatever statistical method is used they also support the statement that the relatively high proportion of euthyroid subjects in the series of patients studied by Dr. D'Haene and his colleagues may explain a considerable part of the observed difference between the "pooled" $r$ values in the two investigations.

On the other hand, I disagree with this approach to the important problem of selecting the most appropriate thyroid function test. Correlation coefficients merely express the degree of relative correspondence. The article by Dr. D'Haene and his colleagues leaves the impression that the F.T.I. is considered the better parameter because of the imperfect correlation between E.T.R. and F.T.I. This conclusion is subject to criticism as the F.T.I. is not the perfect thyroid function test. The possibility exists that the dissimilarity discovered by the correlation analysis is in favour of E.T.R. in terms of helping the clinician to establish the thyroid status of his patients.-I am, etc.,

JøRGEN VESTERDAL JøRGENSEN Frederiksborg County Hospital, Hillerod, Denmark

1 Wellby, M. L., O'Halloran, M. W., and Marshall, J., Clinica Chimica Acta, 1973, 45, 255.

\section{Thrombolytic Therapy in}

\section{Haemolytic-uraemic Syndrome}

SIR,-Some of the statements made by Dr. J. Stuart and others in their article on thrombolytic therapy in the haemolyticuraemic syndrome, (27 July, p. 217) require 
Haemolytic-Uraemic Syndrome: Comparison of Treatment Regimens (All Ages)

\begin{tabular}{|c|c|c|c|c|}
\hline Treatment & $\begin{array}{l}\text { Total No. } \\
\text { of Cases }\end{array}$ & $\begin{array}{l}\text { Deaths during } \\
\text { Acute Illness }\end{array}$ & $\begin{array}{c}\text { Chronic Renal } \\
\text { Disease at } \\
\text { Follow-up** }\end{array}$ & $\begin{array}{l}\text { Normal at } \\
\text { Follow-up }\end{array}$ \\
\hline $\begin{array}{l}\text { Symptomatic only }+ \\
\text { Heparin for less than } 7 \text { days } \\
\text { Heparin for } 7 \text { or more days } \\
\text { Streptokinase, heparin and aspirin, } \\
\text { and/or dipyridamole }\end{array}$ & $\begin{array}{r}22 \\
6 \\
8 \\
8\end{array}$ & $\begin{array}{l}9 \\
3 \\
2 \\
2\end{array}$ & $\begin{array}{l}5 \\
2 \\
2 \\
0\end{array}$ & $\begin{array}{l}8 \\
1 \\
4 \\
6\end{array}$ \\
\hline
\end{tabular}

* Patients in all treatment groups received dialysis and blood transfusion as necessary. Review of medical record showed no shrinking differen

**Shown by presence of hypertension and/or raised serum urea or creatine at least three months after acute illness.

controlled studies of heparin treatment versus supportive treatment, but a review of the available literature ${ }^{1}$ strongly suggests that in most published series heparin has been of value in the treatment of the haemolyticuraemic syndrome.

The use of thrombolytic therapy in the haemolytic-uraemic syndrome cannot be assessed simply by selecting those patients who have failed to respond to conventional therapy over prolonged periods or who present after some weeks of treatment at another institution. Such patients are obviously a selected group in whom improvement or cure from any form of therapy is most unlikely. Furthermore, the efficacy of thrombolytic therapy cannot be assessed only on the basis of reduction of mortality during the acute phase of the disease. In this sense it is particularly relevant that $52 \%$ of the children described by Gianantonio et al. ${ }^{2}$ had a high incidence of residual renal abnormalities, and we have observed similar findings (see table). ${ }^{3}$ The reduction of long-term sequelae of the haemolytic-uraemic syndrome reported by Monnens et al. ${ }^{4}$ and by Powell and Ekert ${ }^{5}$ is a strong indication for the use of thrombolytic therapy in this disease. There seems little to be gained from conservative management during the acute phase of the illness when probably half of the children may end up as renal cripples.

Four lines of evidence have been used to indicate that the haemolytic-uraemic syndrome is the clinical counterpart of the Schwartzman reaction, in which repeated sublethal triggers produce a hypercoagulable state with fibrin deposition. These are: (1) occurrence of impaired renal function and a haemorrhagic tendency in both circumstances; (2) fragmentation of red cells and thrombocytopenia in both circumstances; (3) fibrin deposition in the renal arterioles and glomerular capsules with partial or complete cortical necrosis; and (4) response to anticoagulants. It is clear from experimental work that the Schwartzman reaction can be prevented by heparin if it is given early. Likewise, thrombolytic therapy can prevent the Schwartzman reaction if given within four hours of the provocative injection of the triggering agent. Thus the selection of patients for anticoagulant and thrombolytic therapy on the basis of failed response to conservative treatment will ensure that very few, if any, will obtain benefit from this form of treatment. -I am, etc.,

E. EKERT

Royal Children's Hospital Research Foundation,

Royal Children's Host
Victoria, Australia

1 Proesmans, W., and Eeckles, R., fournal of Pediatrics, 1974, 85, 142 .
2 Gianantonio, C. A., et al., fourmal of Pediatrics,
1968, 72, 757.

3 Ekert, H., Paediatrician. In press.
Monnens, L.. et al., Acta Helvetica Paediatrica, $1972,21,45$.

Podiatrics, 1974, 84, 345.
Pcta

\section{E.C.T. and Cardiac Arrhythmia}

SIR,-I would be grateful for space to support Dr. P. J. Ward's letter (26 October, p. 229), particularly his last paragraph.

In my experience it is not reasonable to think in terms of a "mortality rate." I have administered thousands of convulsive treatments by chemical, inhalant, and electrical induction and the worst accident so far was a broken dental plate. (I always leave dentures in when there are odd teeth which need to be supported during treatmentthey are removed immediately afterwards.) This technique has proceeded from "straight" E.C.T. to treatments with anaesthetics alone and then with decamethonium (C.10), gallamine, and suxamethonium

Dr. Ward mentions that tranquillizers, antidepressants, and barbiturates do not have obvious inhibitory effects on the induced convulsion, but in the course of my study of inhalation induction with flurethyl my colleagues Drs. A. Watson and Jean Harrison established that diazepam does have a marked inhibitory effect and that thiopentone inhibits to a greater degree than methahexatone; nevertheless, I prefer thiopentone anaesthesia to ensure that the patient sleeps long enough to permit restoration of orientation on waking. I also prefer to use calibrated apparatus to establish the minimum discharge necessary for therapeutic response. With so many unwanted side

\section{Consultant Contract}

SIR-It is sad to read of the profession's preparations for applying sanctions in an attempt to resolve this dispute when our motives are so open to misrepresentation. We cannot expect to retain public sympathy so long as the press can claim that our main concern is with our earnings from private practice. We shall shortly need all the public support we can get for our views on the much more serious problem of underfinancing in the Health Service, and we would be wise to negotiate a compromise which could be acceptable both to the Government and to the profession. Such a compromise is not hard to find. We should acknowledge at the outset that the Government is committed to a separation between private practice and the hospital service. Instead of opposing this we should ensure that a suitable alternative is available within the N.H.S. which would satisfy the needs of the majority of potential private patients. An extension effects and interactions of treatment the simpler the better. E.C.T. is one therapeutic weapon the administration of which is not very well taught.-I am, etc.,

L. ROSE

London W.1

\section{Community Hospitals}

SIR,-The Bath District Medical Committee feels deep concern at the policy which is currently being put forward by the Department of Health and Social Security in their recent report on the development of community hospitals. ${ }^{1}$

The Bath Health District is perhaps unique in having 22 local hospitals in the towns which surround the City of Bath, and those working for the district have a special knowledge of the benefit of such an arrangement. The majority of the consultants from the district general hospital in Bath regularly visit these local hospitals. As a result there is a very close relationship between the consultant and family practitioner and mutual understanding of each other's problems and the patient's needs. This leads to better treatment of the patient.

In particular, the committee felt that if all surgery, obstetric, and other acute work was to be carried out in the district general hospital, then community hospitals would be left to care mainly for geriatric patients, and staff, particularly nursing staff, would have their range of work restricted, which would result in greatly diminishing interest and morale. This will be detrimental to the recruitment of nursing staff. It would seem that unless the Department's proposals are modified the service offered at present by our local hospitals could well deteriorate. -We are, etc.,

Bath

HOWELL JOHN Chairman

JoHN E. U. Moxon Vice-chairman John G. Meadows Bath District Medical Committee

1 Department of Health and Social Security. Community Hospitals: Their Role and Development in the Nation

of the present amenity beds system to a full "special amenities service" would provide such an alternative.

The recent Government proposals for a new consultant contract appear to be unacceptable to any section of the profession in their present form. However, a careful reading of the Health Departments' papers to the Owen Committee (16 November, p. 421) indicates the direction in which the contract proposals could be modified without conflicting with the principles enunciated by the Departments. Accordingly, the following modification to the contract is suggested.

The full-time consultant, while being debarred from private practice, should nevertheless be allowed to treat "special amenity" patients. The hospital authorities would retain all fees up to a threshold annual value equal to the sum of the "complete allowance" and any career supplement or distinction award payable only to full-time 